\title{
FACTORS INFLUENCING DEVELOPMENT OF GREEN WOMEN'S ENTREPRENEURSHIP IN SERBIA
}

\author{
Nina Mitic ${ }^{1}$, Bosiljka Srebro², Jovanka Popovic ${ }^{3}$, Goran Kvrgic ${ }^{4}$, Stevica Dedjanski ${ }^{5}$ \\ *Corresponding author E-mail: jovanka.popovic@famns.edu.rs
}

A R T I C L E I N F O
Original Article
Received: 13 March 2021
Accepted: 25 May 2021
doi:10.5937/ekoPolj2103627M
UDC 346.26:347.156-
055.2(497.11)

Keywords:

female entrepreneurs, green economy, sustainable development, standards and technical, regulations,

JEL: L26, O30, M21, B54

\begin{abstract}
A B S T R A C T
Environmental demanding situations require businesses to innovative as a way to gain each environmental, economic and social goals. This article objectives to suggest the elements influencing improvement of green female entrepreneurship thinking about the improvement possibilities thru standardization and gender equality inherent within side the green economy. Using the methods of regression evaluation with the aggregate of Likert's scale approach, 226 woman entrepreneurs from Serbia in 2021 have been involved in the research. The findings display female entrepreneurship however also, that there may be inadequate interest been committed to them within side the procedure of greening their enterprise in green economy support measures for small and medium companies.
\end{abstract}

(C) 2021 EA. All rights reserved.

\section{Introduction}

The significance of entrepreneurship is specifically applicable in dynamic business enterprise environment, when you consider that smaller scale organizations are flexible,

1 Nina Mitic, $\mathrm{PhD}$ studies, Faculty of Applied Management, Economics and Finance, 24 Jevrejska St., 11000 Belgrade, University of Business Academy Novi Sad, Serbia, E-mail: nina.mitic58@gmail.com, ORCID ID (https://orcid.org/0000-0002-3104-3738)

2 Bosiljka Srebro, PhD studies, Faculty for Organizational Sciences, 34 Jove Ilica St., 11000 Belgrade, Serbia, Belgrade University, Phone: +38162 333350, E-mail: bs20165052@, student.fon.bg.ac.rs, ORCID ID (https://orcid.org/0000-0003-3642-7981)

3 Jovanka Popovic, PhD, Assistant Professor, Faculty of Management, University UnionNikola Tesla, Belgrade, Njegoševa 1a, 21205 Sremski Karlovci, Serbia, Phone: +381 64 1345512, E-mail:jovanka.popovic@famns.edu.rs, ORCID ID (https://orcid.org/00000003-0263-0295)

4 Goran Kvrgic, PhD, Full Professor, Faculty of Management, University Union- Nikola Tesla, Belgrade, Njegoševa 1a, 21205 Sremski Karlovci, Serbia, Phone: +381 658099899 , E-mail:goran.kvrgic@famns.edu.rs, ORCID ID (https://orcid.org/0000-0002-1261-4590)

5 Stevica Dedjanski, PhD, IPS Institute for political studies, Belgrade, 36 Svetozara Markovica St., 11000 Belgrade, Serbia, Phone: +381 65 8147800, E-mail: stevica.dedjanski@fdn.edu. rs, ORCID ID (https://orcid.org/0000-0002-5144-3675). 
progressive and adaptable to speedy modifications within side the market (Schumpeter, 2017; Drucker, 2002). There is an in depth literature on the overall position and significance of entrepreneurship (Duflo, 2012; Grozdanic, 2009; Kvrgic, 2018; Popovic, 2020), however much less studies on distinctive factors of female entrepreneurship, what has motivated the authors of the paper to awareness the gender issue, and greater exactly on green female entrepreneurship (De Bruin, Brush \& Welter, 2006). Along with the world of small and medium-sized organizations (Jovanovic \& Lazic, 2018), female entrepreneurship is vital for economy, GDP growth, employment improvement, for the country as the entrepreneurial region, realization of gender issues of GDGs.

Serbia has rolled out measures and programs to stimulate SMEs innovative, financial, market performance (Statistical Office of Serbia; Ministry of Economy, 2018). So, the institutional framework has been strengthened, permitting extra attention of SMEs' pastimes in coverage making, the Council for SMEs, Entrepreneurship and Competitiveness have become more operative and supportive. In addition to tracking and coordinating the implementation of the SME Development Strategy 2015-20, it additionally offers tips and initiates custom designed programs for SMEs, beginning a female enterprise has come to be easier, quicker and cheaper.

Support measures for SMEs have won traction, improving basic monetary and nonfinancial aid to SMEs, and growing the scope of female enterprise aid offerings to encompass a much broader variety of custom designed programs (Voinovich, Zelenovic \& Cvijanovic, 2017). The motivation for the studies on this paper are the demanding situations for coverage makers and SMEs in adopting environmentally sound practices, accreditation and standardization roles in green economy. Also of interest of authors was SMEs' attention of the possibilities supplied through going green, making sure greater qualitative aid and complementarity most of the diverse support measures in green economy, standardization implementation and different friendly framework initiatives (Wysocki, 2021; 2016; Vojteski, 2012). This paper pursuit to discover a number of the crucial dilemmas related to the institutional SMEs support in green economy and standardization confronted via way of means of female businesses importance. Based on the literature on women s entrepreneurship and SMEs development in Serbia the paper offers an outline of current framework on female entrepreneurs, accompanied via way of means of an outline of the studies design, studies findings and hints for practice.

\section{The women's entrepreneurship in Serbia framework}

The environmental issues are seemed to be the important goal in the back of ecoinnovation (EC, 2011; Ekins, 2010). Nevertheless, its implementation can also be due to value reduction, more manufacturing performance or advanced product quality, or innovative initiatives. The implementation of eco-innovation additionally has a sizeable effect at the picture of the entity, and its products (Eryigit \& Özcüre, 2015; Lapreche \& Uzunidis, 2012; EC, 2012), supporting eco-innovations in enterprises (Paraschiv, et al.2012). 
In 2020 SMEs ruled the economy's commercial enterprise quarter, accounting for $99.8 \%$ organizations of the whole enterprise population. The large majority have been micro organizations (96.2\%, 344281 firms), and small companies (from 10-forty nine employees, 10 583). SMEs hired almost $65 \%$ of the whole labour force, at the same time SMEs generated an envisioned 54.1\% value added in 2017. 39.3\%, SME make contributions to exports (Ministry of Economy of Serbia, 2018).

According to the Gender Analysis for Serbia report, the share of entrepreneurial women has been increasing - from $7.9 \%$ in 2007 to $14.9 \%$ in 2011 and to $31.7 \%$ in 2014. However, only 19.6\% of female entrepreneurs run enterprises (Dokmanovic, 2016). The score for

According to the Gender Analysis (Dokmanovic, 2016) the proportion of female entrepreneurs has been increasing - from $7.9 \%$ in 2007 to $14.9 \%$ in 2011 and to $31.7 \%$ in 2014. However, handiest $19.6 \%$ of female entrepreneurs run companies. The rating for women's entrepreneurship stands at 4.35 (OECD, 2019).

The Strategy for Supporting the Development of Small and Medium Enterprises, Entrepreneurship and Competitiveness 2015-2020 and its action plan include women's entrepreneurship as an important pillar. Cross-sectoral policy support to women's entrepreneurship can be seen in the plans of National Employment Service, Gender Equality Strategy(2016-2020), Protection strategy against Discrimination and Implementation Action Plan (2014-2018), with the the coordination Body for Gender Equality. Serbia's score of 4.55, according to the (EC, 2018, EPA, 2014) in the area of standards and technical regulations and alignment with the EU acquis is the highest in the Western Balkans. Serbian performance in the area of SME greening is quite low at 2.21, and along with Albania, Serbia is among the three lowest-performing economies in the region.

The Strategy for SMEs and Competitiveness 2015-2020 development and its motion plan encompass women's entrepreneurship as an critical pillar. Cross-sectoral coverage help to women's entrepreneurship may be visible withinside the plans of National Employment Service, Gender Equality Strategy(2016-2020), Protection method towards Discrimination and Implementation Action Plan (2014-2018), with the the coordination Body for Gender Equality. Serbia's rating of 4.55, in line with the (EC, 2018, EPA, 2014) withinside the vicinity of requirements and technical guidelines and alignment with the EU acquis is the very best withinside the region, but Serbian overall performance withinside the vicinity of SME greening is pretty low at 2.21, and in conjunction with Albania, Serbia is a few of the 3 lowest-appearing economies withinside the region.

Environmental guidelines concentrated on SMEs are protected in countrywide strategic documents. The advertising of eco-innovation and support measures efficiency (especially power efficiency) as critical targets beneath Neath the pillar at the Improvement of the sustainability and competitiveness of SMEs are underlined, the measures helping those targets, the enterprise of attention elevating workshops on eco- 
innovation and the green economy, the supply of professional help to the enterprises which might be making ready eco-innovation mission proposals for Horizon funding. Information on environmental standards, eco labelling, and inexperienced procurement is supplied through Eco portal.

Some superb traits as regards economic incentives are designed, just like the Green Innovation Vouchers, sports via DRIVE Programme, Green Fund reestablishment, however now no longer nonetheless covering the SMEs. Serbia's records portal TEHNIS gives records on export necessities and compliance mechanisms, in which available, are fragmented.

A well-designed and complete pool of records might consequently advantage SMEs, which frequently do now no longer have time, sources or the employees potential to acquire records from diverse sources, establishments and websites.

To replicate EU sectoral regulation the country wide regulation has been similarly amended, with a giant development made in transposing the European requirements into country wide ones (The Institute for Standardization of Serbia have become a complete member of the European Committee for Standardization (CEN) and (CENELEC).

Serbia is likewise a complete member of the International Organization for Standardization (ISO), the International Electrotechnical Commission, and the European Telecommunications Standards Institute, properly incorporated into the worldwide metrology network.

According to OECD data (2018) Serbia has 628 authorized conformity evaluation bodies $(\mathrm{CABs})$, forty nine of that are designated, with the giant boom of $20 \%$ withinside the variety of packages for accreditation. Serbia's overall performance in presenting facts on requirements and elevating attention in their advantages is the very best withinside the Western Balkan region, however nevertheless with out the implementation of any ICT-primarily based totally modern equipment which intention to facilitate SME participation in growing requirements or economic measure.

\section{Hypothetical research model}

There are defined further 3 variables for the research:

2 independent variables:

(A) Variable : Standards and technical regulations (abbr.STRI), and

(B) Variable: green economy support measures (abbr.GESM), and 1 dependent variable:

(C) Variable: Green female entrepreneurs development (abbr.GFED).

One main $\left(H_{0}\right)$ and two auxiliary $\left(H_{1}, H_{2}\right)$ hypotheses are defined (Graph 1$)$ : 
$H_{0}=$ The level of green female entrepreneurs' development depends of support measures in green economy and the level of standards and technical regulations implementation.

$H_{1}=$ The level of standards and technical regulations implementation impacts development level of green female entrepreneurs.

$\mathrm{H}_{2}=$ The level of green economy support measures impacts the development level of green female entrepreneurs.

Figure 1. Hypothetical research model

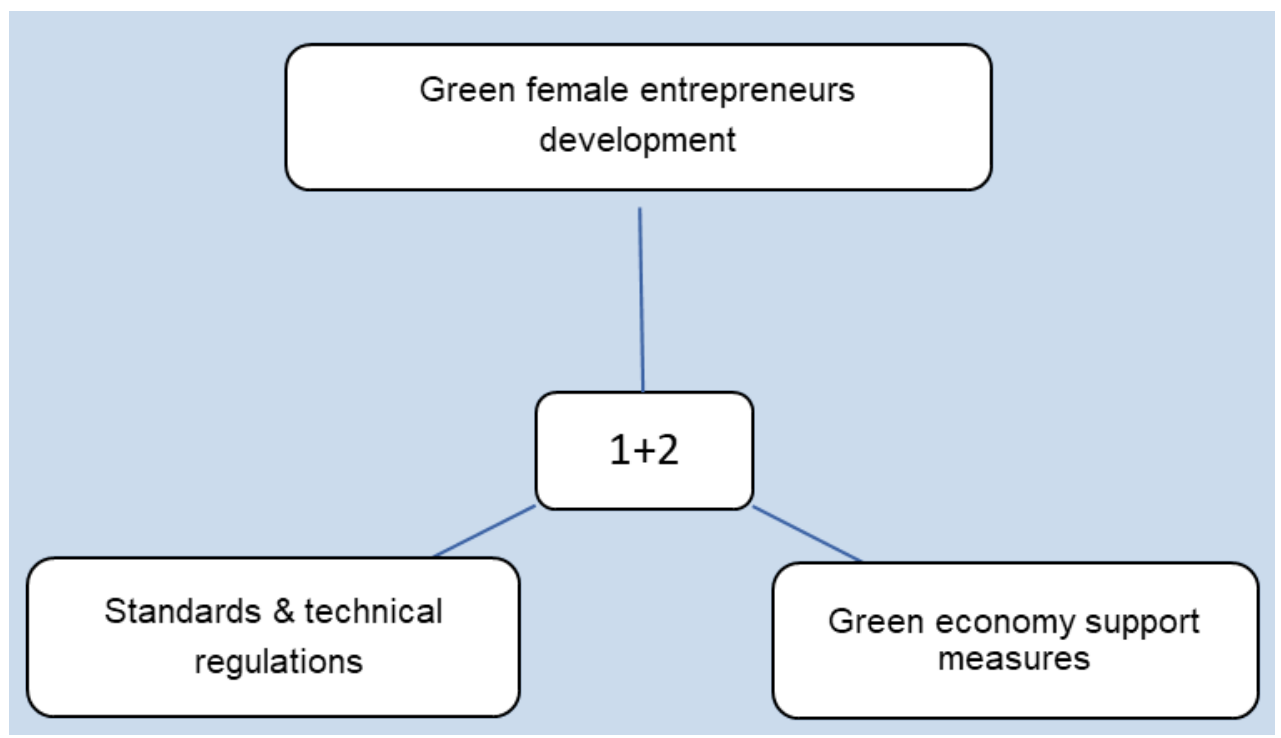

\section{Methods and materials}

Through this studies, the authors will discover the position of support measures, barriers, enablers and vital dilemmas that a success female entrepreneurs are confronted with in maintaining and developing their businesses in green economy, inclined to fill additionally the present hole in studies and literature on progressive interest of women $\mathrm{s}$ entrepreneurship (Agarwal, 2018; Awan et al, 2020; Cvijanovic, 2020; Doran \& Ryan, 2012; Dutta, 2020; Grozdanic, Radovic, Jevtic. 2013). The foremost goal of the studies is to evaluate the the extent of help to female businesses in Serbia, and to become aware of a number of the vital dilemmas related to the institutional SMEs support for green SMEs.

In order to assess the growth capability of female entrepreneurs in green economy in Serbia, a subject survey become conducted. The questionnaire become designed to acquire statistics and perceptions of female entrepreneurs at the elements applicable for the evaluation of growth capability, scandalization and support emasures for green economy in Serbia withinside the green women's entrepreneurship development (Dimitrijevic et al. 2017; Nhamo \& Mukonza, 2020; Grozdanic et al. 2009; 2013). 
Methods used are correlation and regression analysis, found out withinside the statistical software program IBM SPSS 26 and IBM SPSS AMOS 26. Qualitative information that specialize in figuring out their evaluation at the guide measures for SMEs in green economy and the standards and technical regulations and their impacts on green women's entrepreneurship development in Serbia has been additionally a part of the questioner. The Likert's scale approach changed into used to qualify their solutions with the weighted score scale from 1-5: 1 - I absolutely disagree, 2 - I disagree, 3 - indecisive, 4 - I agree and 5 - I absolutely believe given claims. The statements approximately the have an effect on of which the studies individuals said include 10 elements inside 3 described classes as enterprise dilemmas at the have an effect on at the growth of women's enterprises.

The research covers the entire territory of Serbia. It includes 226 female entrepreneurs and enterprises owned by women. The on line questioner with questions about industry enterprise sectors, wide variety of employees, the earnings with the origin of the businesses interviewed was provided in 2021.

Attitudes are described for values. 54, 38\% of the sample are female entrepreneurs from the food processing industry and trade, 29, 82\% from tourism, hospitality and the touristic events organization and 15, 78 \% from ICT and marketing services. Most of women enterprises come from small and micro enterprises, as: $69,73 \%$ had from $€$ 2000 to $€ 50,000$ annual, and 74, 99\% have been with 1-20 employees. Only $13 \%$ found out their sales via export activities (Table 1).

Table 1. Descriptive statistics

\begin{tabular}{|c|c|c|}
\hline & Count & Prob \\
\hline Total No. of participants & 228 & 1.00000 \\
\hline \multicolumn{3}{|l|}{ Industry sector } \\
\hline Food processing and trade & 124 & 0.5438 \\
\hline Tourism, hospitality and touristic events organization & 68 & 0.2982 \\
\hline ICT and marketing services & 36 & 0.1578 \\
\hline \multicolumn{3}{|l|}{ Revenue in 2020.} \\
\hline From $€ 2000$ to $€ 10.000$ & 34 & 0.1491 \\
\hline From $€ 10.001$ to $€ 50.000$ & 125 & 0.5482 \\
\hline From $€ 50.001$ to $€ 100.000$ & 46 & 0.2017 \\
\hline Over $€ 100.000$ & 23 & 0.1008 \\
\hline \multicolumn{3}{|l|}{ No. of employees in the enterprise } \\
\hline From 1 to 10 employees & 80 & 0.3508 \\
\hline From 11 to 20 employees & 91 & 0.3991 \\
\hline From 21 to 30 employees & 34 & 0.1491 \\
\hline From 31 to 50 employees & 18 & 0.0789 \\
\hline Over 50 employees & 5 & 0.0219 \\
\hline \multicolumn{3}{|l|}{ Revenue origin } \\
\hline Domestic market & 198 & 0.8684 \\
\hline Export & 30 & 0.1315 \\
\hline
\end{tabular}


By correlation and regression analysis, the following mean scores of attitudes to the stated claims were obtained (Tables 2-4):

Table 2. Factors and values for the Standards and technical regulations

\begin{tabular}{|c|l|c|}
\hline No. & \multicolumn{1}{|c|}{ Set claims } & Mean scores \\
\hline $\mathbf{A}_{1}$ & $\begin{array}{l}\text { The SMEs \& entrepreneurs access to standardization (participation in } \\
\text { developing standards) affects GFED }\end{array}$ & 3.6885965 \\
\hline $\mathbf{A}_{2}$ & $\begin{array}{l}\text { The level of the harmonization with EU acquis in Technical regulations, } \\
\text { Standardization, Accreditation \& Metrology affects GFED }\end{array}$ & 3.9736842 \\
\hline $\mathbf{A}_{3}$ & The financial support to SMEs \& Market surveillance affects GFED & 3.8991228 \\
\hline $\mathbf{A}_{4}$ & The awareness raising and information affects GFED & 3.8684211 \\
\hline
\end{tabular}

Table 3. Factors and values for the green economy support

\begin{tabular}{|c|l|c|}
\hline No. & \multicolumn{1}{|c|}{ Set claims } & Mean scores \\
\hline $\mathbf{B}_{1}$ & $\begin{array}{l}\text { The framework for environmental policies targeting SMEs\& } \\
\text { entrepreneurs affects GFED }\end{array}$ & 3.9385965 \\
\hline $\mathbf{B}_{2}$ & The incentives for SMEs \& entrepreneurs greening affect GFED & 3.8508772 \\
\hline $\mathbf{B}_{3}$ & The instruments for SMEs \& entrepreneurs greening affect GFED & 3.7894737 \\
\hline
\end{tabular}

Table 4. Factors and values for the green female entrepreneurs)development(GFED

\begin{tabular}{|c|l|c|}
\hline No. & \multicolumn{1}{|c|}{ Set claims } & Mean scores \\
\hline $\mathbf{C}_{1}$ & The level of planning and design of GFED affects its development & 4.0087719 \\
\hline $\mathbf{C}_{2}$ & The level of the implementation of principles of GFED affects its development & 3.8245614 \\
\hline $\mathbf{C}_{3}$ & The monitoring and evaluation of GFED enables its development & 3.9035088 \\
\hline
\end{tabular}

\section{Variable (AC) correlation and regression analysis}

Theoretical system model (AC) is shown in (Figure 2). The model make two variables (A) independent) and (C) dependent variable.

Figure 2. Theoretical system model AC

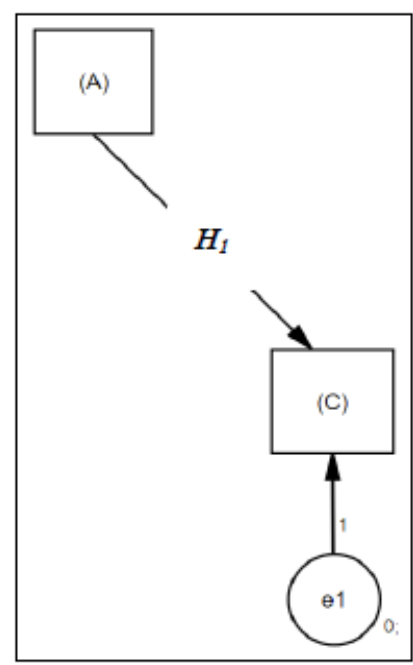


Figure 2 (on the left) performs the system model evaluation. 0.631565 is the value of the coefficient of determination showing the opportunity that the dependent variable (C) can be explained with $63.15 \%$ by independent variable (A). Based on this, it can be concluded that the correlation coefficient between (A) as the independent variable and $(\mathrm{C})$, the dependent variable is 0.79471 , and it is strong correlation between them.

Figure 3. Standard (left) and non-standard (right) contribution sizes of the AC system model

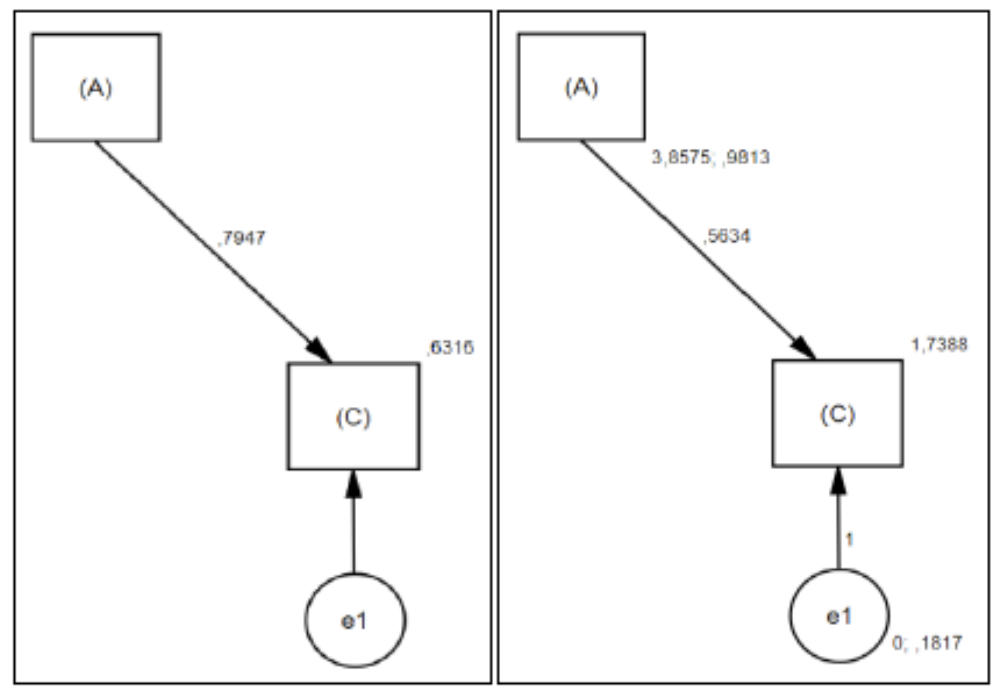

Table 5 presents statistical significance assessment. It is $[\mathrm{F}(1,226)=387.4052, \mathrm{p}<0.0001]$.

Table 5. ANOVA

\begin{tabular}{|c|r|r|r|c|}
\hline Source & DF & Sum of Squares & Mean Square & F Ratio \\
\hline Model & 1 & 71.03074 & 71.0307 & 387.4052 \\
\hline Error & 226 & 41.43709 & 0.1833 & Prob $>$ F \\
\hline C. Total & 227 & 112.46784 & & $<0.0001$ \\
\hline
\end{tabular}

Based on these data, the first hypothesis $\boldsymbol{H}_{1}=$ The level of standards and technical regulations implementation impacts development level of green female entrepreneurs in Serbia can be confirmed.

Figure 3 (on the right) performs the system model evaluation non-standard contribution values. The mean score for the independent variable (A) is 3.8575 . For the independent variable (A) 0.9813 is the value of the magnitude of the variance. 0.1817 is the variance for the dependent variable $(\mathrm{C})$. Based on the presented data, a multiple regression equation can be formed (formulas 1 and 2), which reads: 


$$
y=1.7388285+0.5634419 \cdot x_{1}
$$

or

The level of green female entrepreneurs development

$$
=1.7388285+0.5634419
$$

- The level of standards and technical regulations implementation A diagram of the multiple regression equation for variables (AC) is given in Figure 4.

Figure 4. A diagram of the multiple regression equation for variables (AC)

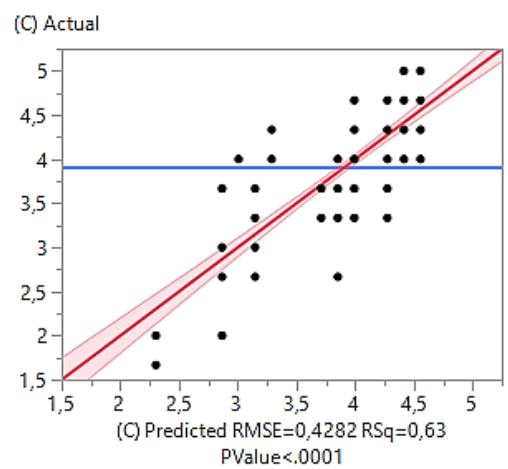

\section{Variable (BC) correlation and regression analysis}

Theoretical system model (BC) is shown in Figure 5. The system model consists of an independent variable (B) and a dependent variable (C).

Figure 5. Theoretical system model BC

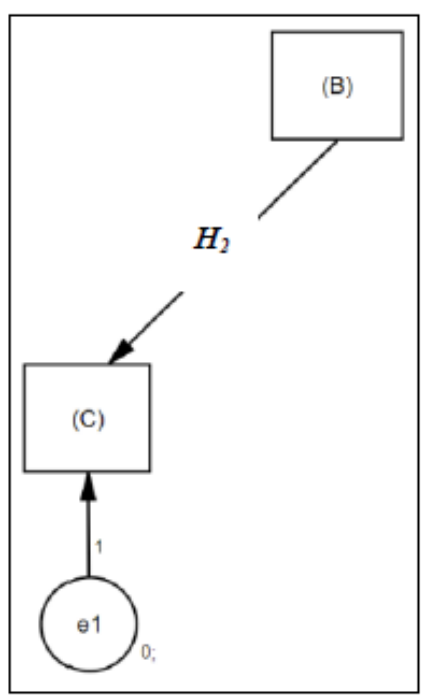


The basic evaluation of the system model is performed at Figure 5 (left). 0.169172 is is the value of the coefficient of determination, which suggests that with $16.91 \%$ the dependent $(\mathrm{C})$ variable can be explained by (B).variable As the coefficient of correlation between these 2 variables (B) and (C) is 0.41130 , the correlation between them.is weak.

Figure 5. Standard (left) and non-standard (right) contribution sizes of the BC system model
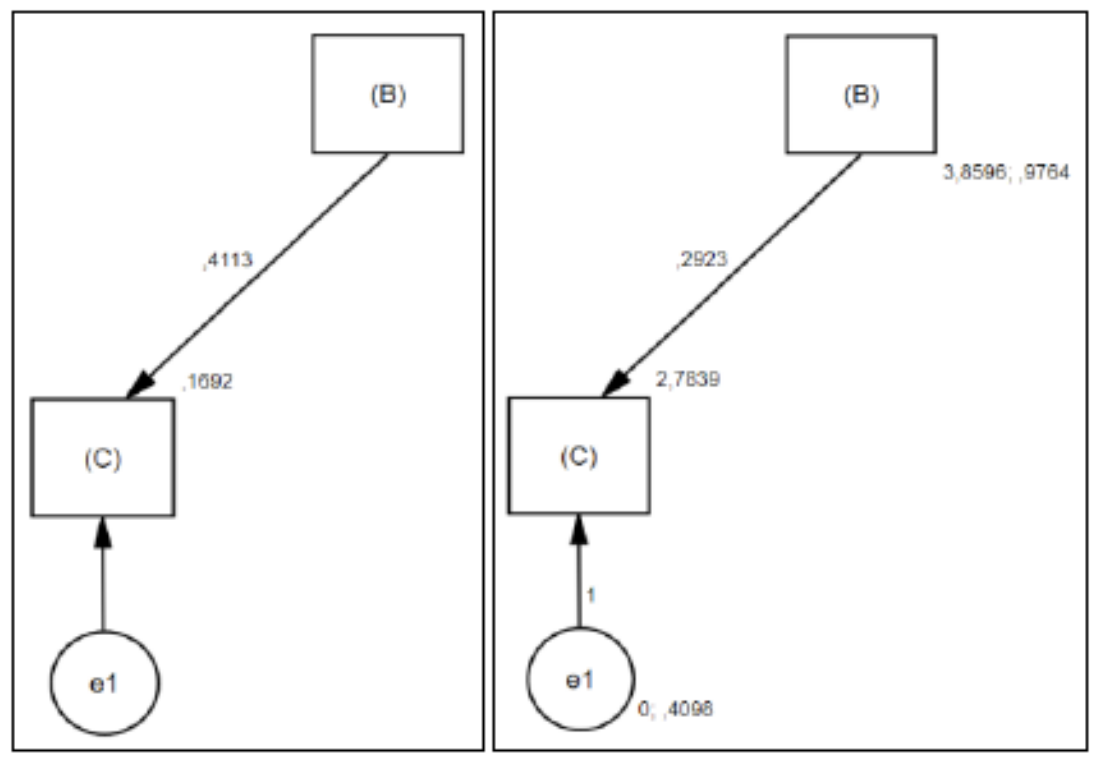

The statistical significance assessment is $[\mathrm{F}(1,226)=46.0177, \mathrm{p}<0.0001]$, and is presented in Table 6.

Table 6. ANOVA

\begin{tabular}{|c|r|r|r|c|}
\hline Source & DF & Sum of Squares & Mean Square & F Ratio \\
\hline Model & 1 & 19.02638 & 19.0264 & 46.0177 \\
\hline Error & 226 & 93.44146 & 0.4135 & Prob $>$ F \\
\hline C. Total & 227 & 112.46784 & & $<0.0001$ \\
\hline
\end{tabular}

Based on these data, the second specific hypothesis can be confirmed, $\boldsymbol{H}_{2}=$ the level of green economy support measures impacts the development level of green female entrepreneurs.

Figure 5 (right) presents the set system model non-standard contribution values. is the The independent variable (B). mean score is 3.8596. The magnitude of the variance for the independent variable (B) is 0.9764 , and the variance for the dependent variable (C) is 0.4098 . Based on the presented data, a multiple regression equation (formulas 3 and 4) can be formed, which reads: 


$$
y=2.7839305+0.2923453 \cdot x_{2}
$$

$\mathrm{Or}$

The level of green female entrepreneurs development $=$

$$
\begin{aligned}
& =2.7839305+0.2923453 \\
& \text { - The level of green economy support measures }
\end{aligned}
$$

A diagram of the multiple regression equation for the variables (BC) is given in Figure 6.

Figure 6. A diagram of the multiple regression equation for the variables (BC)

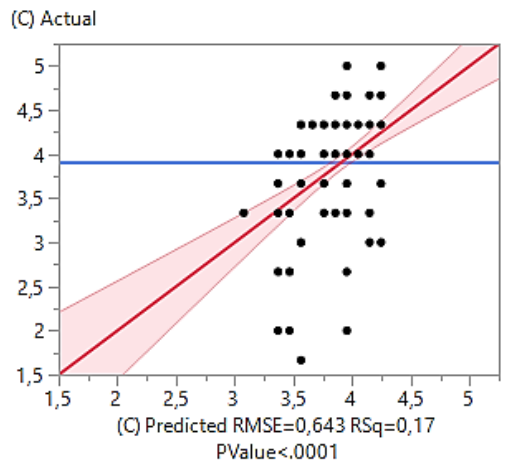

\section{Variable $(\mathrm{ABC})$ multiple correlation and regression analysis}

Presented theoretical system model (ABC) consists of independent variables (A) and (B) and the dependent variable (C). (Figure 7).

Figure 7. Theoretical system model for (ABC)

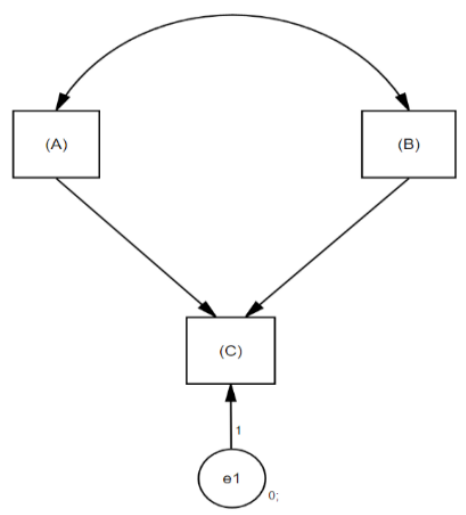

The basic standard analysis of the system model is performed in Figure 8 . The worth of the coefficient of determination is 0.822772 which implies that with $82.27 \%$ variability of the variable (C). may be explained by different variables. The result support sturdy 
correlation of variables. -0.7947 value of correlation coefficients shows that the biggest correlation is found between the dependent variable $(C)$.and independent $(A)$ variable. The littlest size of the correlation is found between the independent variables (A) and (B) and it's negative and insignificant and amounts to -0.0324 . The biggest influence on the variable $(\mathrm{C})$ has the independent variable $(\mathrm{A})$ and is 0.80888 , and also the smaller influence has the independent variable (B) is 0.437502 .

Figure 8. Standard contribution sizes of the system model for (ABC)

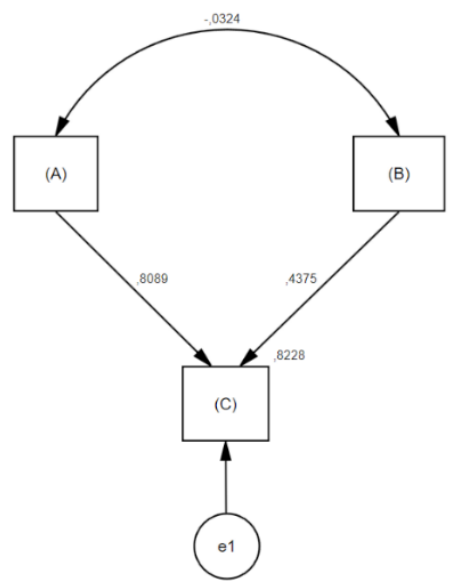

Table 7 presents the statistical significance assessment, that is $[\mathrm{F}(2,225)=522.2756$, $\mathrm{p}<0.0001]$.

Table 7. ANOVA for variable (C)

\begin{tabular}{|c|r|r|r|r|}
\hline Source & DF & Sum of Squares & Mean Square & F Ratio \\
\hline Model & 2 & 92.53539 & 46.2677 & 522.2756 \\
\hline Error & 225 & 19.93245 & 0.0886 & Prob $>$ F \\
\hline C. Total & 227 & 112.46784 & & $<0.0001$ \\
\hline
\end{tabular}

Based on these data, the set main hypothesis can be confirmed $\boldsymbol{H}_{0}$ : The level of green female entrepreneurs development depends of support measures in green economy and the level of standards and technical regulations implementation.

Non-standard contribution values for the set system model are given in Figure 9. The the independent variable (A) has 3.8575 for the highest mean value, and the lowest for the independent variable (B) is 3.8596. The largest size for the variance is the size of the independent variable (A) 0.9813, and the smallest variance is for the dependent variable $(\mathrm{C})$ and is 0.0674 . The covariance between the independent variables $(\mathrm{A})$ and (B) and is -0.0317 . 
Figure 9. Non-standard contribution sizes of the system model for (ABC)

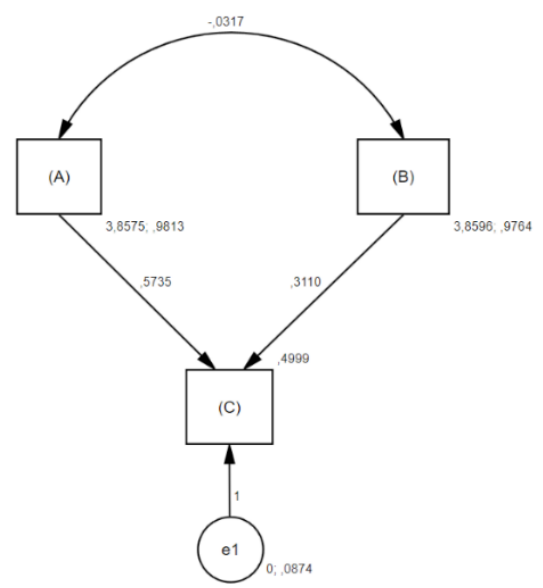

Based on the data from Figure 9, a multiple regression equation can be formed (formulas 5 and 6), which reads:

$$
y=0.4998598+0.5734877 \cdot x_{1}+0.3109654 \cdot x_{2}
$$

or

The level of green female entrepreneurs development $=$

$=0.4998598+0.5734877$

- the level of standards and technical regulations implementation +

$+0.3109654 \cdot$ the level of green economy support measures

Diagram of the multiple regression equation for variables (ABC) is given in (Figure 10)

Figure 10. Multiple regression equation diagram for variables (ABC)

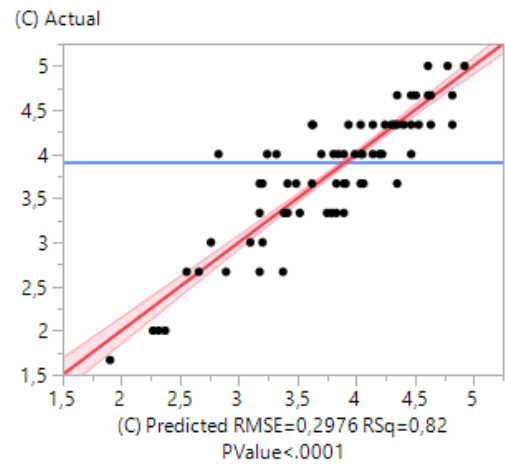




\section{Discussion}

According to key findings on the chosen criteria influencing the level of development of green female entrepreneurs, they referred to environmental issues, green products and services and standards, SMEs and entrepreneurs support measures in green economy are relevant for further green female entrepreneurs development in Serbia. According to the defined variables in the theoretical research model, and multiple regression equation analysis of the key results of the research, the hypotheses are confirmed. So, the influence of standards and technical requirements, metrology, harmonization with the EU and implementation in the area of green economy is found as very high.

The lower grades are given to the group of criteria concerning SMEs and entrepreneurs support measures in green economy, mostly because instruments and incentives are still not developed enough, as well as the coordinative activities among other participating institutions as, finance, education, innovation, economy associations are.

\section{Conclusions}

Based on a literature and findings of the analysis on factors influencing the extent of development of green female entrepreneurs, it are often complete that comprehensive measures are required so as to extend green female entrepreneurs, also as more common and coordinating actions of policy makers, finance, and academia. The results imply to the little share of female victimization programs and support services for SMEs and entrepreneurs in green economy. Their capacities to perform green innovation activities are restricted by their money and human resources. so saying on planning higher promotion of innovative programs of the female entrepreneurs, guaranteeing consolidation of presidency policy actions for green women's entrepreneurs.

There are sensible leads to the standardization and accreditation policy area, seen from the best performing artist within the Western Balkan region for Serbia, however some challenges remain.

To feminine entrepreneurs establishing of green product and repair contact points may be of use. The additional operationalized treatment of the character of SMEs and entrepreneurs greening in the country, because the creation of the body or a unit answerable of coordinative the implementation of SMEs greening measures may be. Enhancing the support to SME greening and green female enterprises is incredibly important, as the inexperienced Innovation Voucher in SMEs' transition to a green economy support is.

\section{Conflict of interests}

The authors declare no conflict of interest. 


\section{References}

1. Agarwal, B. (2018). Gender equality, food security and the sustainable development goals. Curr. Opin. Environ. Sustain, 34, 26-32.

2. Awan, U., Nauman, S., \& Sroufe, R. (2020). Exploring the effect of buyer engagement on green product innovation: Empirical evidence from manufacturers. Bus. Strategy Environ. https://doi.org/10.1002/bse.2631

3. Brush, C. (2009). Women Entrepreneurs: A Research Overview. The Oxford Handbooks of Entrepreneurship in Oxford Handbooks in Business and Management. https://doi.org/10.1093/oxfordhb/9780199546992.003.0023

4. Cvijanovic, D., Ignjatijevic, S., Tankosic, J.V., \& Cvijanovic, V. (2020). Do Local Food Products Contribute to Sustainable Economic Development?, Sustainability 2020, 12(7), 2847, https://doi.org/10.3390/su12072847

5. Dimitrijevic, V., Vukadinovic, P., \& Grozdanic, R. (2017). Legal and Financial Framework for Micro Entrepreneurship Development, Monograph: New Insights And Potential Sources of new Entrepreneurial Growth, SAD, Filodiritto International Proceedings, ISBN 978-88-95922-84-3, 26-42.

6. De Bruin, A., Brush, C., \& Welter, F. (2006). Introduction to the Special Issue: Towards Building Cumulative Knowledge on Women's Entrepreneurship. Entrepreneurship Theory and Practice, 30(5): 585-593., doi: https://doi. org/10.1111/j.1540-6520.2006.00137.x

7. Doran, J., \& Ryan, G. (2012). Regulation and firm perceptron, eco-innovation and firm performance. Eur. J. Innov. Manag., 15, 421-422. [CrossRef].

8. Dokmanovic, M. (2016), Gender Analysis for Serbia, European Commission, http://europa.rs/files/Gender_Equality/Gender-Analysis-Serbia-dec-2016.pdf .

9. Drucker, F.P. (2002). The Discipline on Innovation. Harvard Business Review, 80(8), 95- 100.

10. Duflo, E. (2012). Women empowerment and economic development. J. Econ. Lit., 50, 1051-1079.

11. Dutta, S. (2020). Promoting Women's Entrepreneurship in Distribution of Energy Technologies: Lessons from ENERGIA's WEE Programme. IDS Bull., 51, 7190. https://doi.org/10.19088/1968-2020.106 [CrossRef]

12. EC (2018[14]), Economic Reform Programmes: Western Balkans and Turkey https://ec.europa.eu/neighbourhood-enlargement/sites/near/files/20180417-erpfactsheet.pdf.

13. http://europa.rs/files/Gender_Equality/Gender-Analysis-Serbia-dec-2016.pdf

14. EC. (2012). Eco-innovation the key to Europe's future competitiveness. Available online: https://ec.europa. eu/environment/pubs/pdf/factsheets/ecoinnovation/ en.pdf (accessed on 20 December 2020).

15. EC. (2011). Communication from the Commission to the European Parliament, the Council, the European Economic and Social Committee and the Committee of the Regions. Innovation for a Sustainable Future-the Eco-Innovation Action Plan (Eco-AP). https://doi.org/10.1080/13880290903199425, Available online: http://eur-lex.europa.eu/legal-content/EN/TXT/?uri=CELEX\%3A52011DC0899 (accessed on 3 January 2021). 
16. EC. (2011). Eco-Innovation Action Plan Launched: Helping Business to Deliver Green Growth and Environmental Benefits. 2011. Available online: https:// ec.europa.eu/commission/presscorner/detail/en/IP_11_1547 (accessed on 19 January, 2021).

17. Ekins, P. (2010). Eco-innovation for environmental sustainability: Concepts, progress and policies. Int. Econ. Econ. Policy, 7, 267-290. https://doi.org/10.1007/ S10368-010-0162-z

18. EPA (2014), Green Business Initiative, http://www.epa.ie/waste/nwpp/gbi/\#. W1opW_ZuI2w.

19. Eryigit, N.; Özcüre, G. (2015). Eco-Innovation as Modern Era Strategy of Companies in Developing Countries: Comparison between Turkey and European Union. Procedia Soc. Behav. Sci., 195, 1216-1225. https://doi.org/10.1016/j. sbspro.2015.06.246

20. Grozdanic, R., Radovic-Markovic, M., Jevtic, B. (2013). New Technologies, Green Growth and Jobs, In: Rural Entrepreneurship opportunities for entrepreneurs, 92-112., ISBN 978-86-6069-096-0, Faculty of Business Economics and Entrepreneurship.

21. Grozdanic, R., Radovic-Markovic, M., \& Vucic, M. (2009). Female Entrepreneurship in Serbia. U: GUICHARD, Jean-Paul (ur.), VALTER, Cantino (ur.), DUTTO, Guiseppe (ur.), Radović-Marković, M (ur.), Interantional Monograph: Challenges of economic sciences in the 21st Century: Institute of Economic Sciences, Beograd, 227-237. ISBN 978-86-80315-79-9, [COBISS. SR-ID 1024305040], https://doi.org/10.1007/978-3-319-14209-8 13, Available at: http://ebooks.ien.bg.ac.rs/209/.

22. Grozdanic, R. (2013). Agribusiness and Agro-Industrial Strategies, Policies and Priorities for Achieving Higher Competitiveness, Employability and Sustainability in the Western Balkans Region, International Monography, Fridrich Ebert Foundation, available at: Available at: www.fessoe.de.

23. Grozdanic, R. (2009). Female Entrepreneurship and Local Economic Growth, The Library of Congress Cataloguing-in-Publication Data, published in Canada, Basic Institutional Infrastructural Support Needed for the Development of Women's Entrepreneurship in Serbia, Outskirts Press, and United State. ISBN 978-143-2747-55.

24. Grozdanic, R., \& Radovic-Markovic, M. (2015). Family Businesses Motives for Internationalisation: Evidence from Serbia. In Family Businesses in Transition Economies: management, succession and internationalization. Springer, cop, Heidelberg, pp. 267-292 International Monograph, Springer International Publishing. ISBN 978-3-319-14208-1, COBISS.ID=512290402.

25. Kvrgic, G. (2018). Značaj teritorijalnog kapitala za ruralni razvoj u ekonomiji znanja, Megatrend Review, ISSN 1820-3159, 15(3), 55-68. https://doi. org $/ 10.5937 / \mathrm{megrev} 1803055 \mathrm{k}$.

26. Jovanovic, O., \& Lazic, M. (2018). Women Entrepreneurship in Serbia Potentials and Constraints. Journal of Women's Entrepreneurship and Education, 3-4: 60-72. https://doi.org/10.28934/jwee18.34.pp60-72. 
27. Lapreche, B.; Uzunidis, D. (2012). Eco-Innovation, Knowledge Capital and Evolution of the Firm. IUP J. Knowl. Manag. 10, 14-34

28. Milosevic, D., Popovic, J., Avakumovic, J., Kvrgic, G. (2020). The Impact of the Equity Capital and Trade Credit Financial Sources on The Company's Performances Sustainability, Economics of Agriculture, 67 (3), 735-747. https:// doi.org/10.5937/ekopolj2003735m. Available at: http://bsaae.bg.ac.rs/images/ Ekonomika\%20kompletna/2020/EP\%203-2020.pdf

29. Ministry of Economy (2018), Report on Small and Medium-Sized Enterprises in Serbia for 2017, SME and Entrepreneurship Department, Ministry of Economy of the Republic of Serbia, http://dx.doi.org/10.1787/88893393792.

30. Mujeed, S.; Li, S.; Jabeen, M.; Nassani, A.A.; Askar, S.E.; Zaman, K.; Abro, M.M.Q.; Sriyanto; Jambari, H. (2021). Technowomen: Women's Autonomy and Its Impact on Environmental Quality. Sustainability, 13, 1611. https://doi.org/ $10.3390 /$ su13041611.

31. Mbaye, L.M .(2020). Weather Shocks and Women Empowerment. In Women and Sustainable Human Development; Palgrave Macmillan: Cham, Switzerland, 37-49. doi: https://doi.org/10.1007/978-3-030-14935-2_ 3

32. Nhamo, G.; Mukonza, C. Opportunities for women in the green economy and environmental sectors. Sustain. Dev. 2020

33. OECD \& World Bank. (2019), Serbia: Small Business Act profile, in SME Policy Index: Western Balkans and Turkey 2019: Assessing the Implementation of the Small Business Act for Europe, OECD Publishing, and Paris. doi: https://doi. org/10.1787/354bd091-en

34. Paraschiv, D.M.; Voicu-Dorobantu, R.; Langa, C.; Nemoianu, L. (2012). New Models in Support of the Eco-Innovative Capacity of Companies-A Theoretical Approach. Econ. Comput. Econ. Cybern. Stud. Res, 46, 104.

35. Pirani, N.; Ricker, B.A.; Kraak, M.J. (2020). Feminist cartography and the United Nations Sustainable Development Goal on gender equality: Emotional responses to three thematic maps. Can. Geog. Geogr. Can, 64, 184-198. https:// doi.org/10.1111/cag.12575.

36. Popovic, J., Kvrgic, G., Coric, G., Avakumovic, J., Milosevic, D. (2020) Uncertainty in SMEs' Assessment of Coronavirus Pandemic Risk Impact on Agro-Food Sector In Western Balkans, Economics of Agriculture, 67 (2), 445460. https://doi.org/10.5937/ekoPolj2002445P, available at: http://bsaae.bg.ac.rs/ images/Ekonomika\%20kompletna/2020/EP\%202-2020\%20LQ.pdf

37. Radovic-Markovic, M., Lindgren, C. E., Grozdanic, R., Markovic, D., \& Salamzadeh, A. (2012). Freedom, individuality and women's entrepreneurship education. Entrepreneurship education - a priority for the higher education institutions, 203-208.

38. Rennings, K. (2002). Employment impact of cleaner production on the firm level: Empirical evidence from a survey in five European countries. Int. J. Innov. Manag, 6, 322. doi: https://doi.org/10.2139/ssrn.336522 
39. Schumpeter, J.A. (2017). The Theory of Economic Development: An Inquiry Into Profits, Capital, Credit, Interest, and the Business Cycle, 1st ed.; Routledge: New York, NY, USA

40. Sorensen, C.; Saunik, S.; Sehgal, M.; Tewary, A.; Govindan, M.; Lemery, J.; Balbus, J. (2018). Climate Change and Women's Health: Impacts and Opportunities in India. GeoHealth, 2, 283-297. doi: https://doi.org/10.1029/2018gh000163

41. Statistical Office of Serbia; Ministry of Economy. (2018), Report on Small and Medium-Sized Enterprises in Serbia for 2017, SME and Entrepreneurship Department, Ministry of Economy of the Republic of Serbia. StatLink 2 http:// dx.doi.org/10.1787/888933937926.

42. United Nations.(2030). Goal5:GenderEquality. Goal5:AchieveGenderEqualityand Empower All Women and Girls. doi:https://doi.org/10.1891/9780826190123.0016 Available online: http:/www.un.org/development/desa/disabilities/envision2030goal5.html (accessed on 4 December 2020).

43. UNCTAD. (2013). A Survey on Women's Entrepreneurship and Innovation, available at: https://empretec.unctad.org/wp-content/uploads/2015/01/ UNCTAD_DIAE_ED_2013_1.pdf.

44. Vojinovic, Z., Zelenovic, V., \& Cvijanović, D. (2017). Program of state stupport to agricultural creditin, Economics of Agriculture 1, 1-20.

45. Vojteski-Kljenak, D., Lukic, R., Kvrgic, G. (2012). Green Retail Sale as a Factor of Business Success, Metalurgia International, 17 (11), 127-132. https://kobson.nb.rs/ nauka_u_srbiji.132.html?autor=Kvrgic\%20Goran\&samoar=\#.X2E3xT is2w

46. Wysocki, J. (2021). Innovative Green Initiatives in the Manufacturing SME Sector in Poland. Sustainability, 13, 2386. https://doi.org/10.3390/su13042386

47. Wysocki, J. (2016). Eco-innovations in the development of companies. Marketing \& Rynek, 7, 1066-1078. doi:https://doi.org/10.3390/su13042386

48. Zlatkov-Cvetković, Marina. (2015). Women entrepreneurship in Serbia: A qualitative study of the perceived enabling factors for the female entrepreneurship. Master Thesis, Swedish University of Agricultural Sciences. 